\title{
Kültürel Mirasın Korunması ve Turizm Amaçlı Kullanılmasında Yerel Halkın Algı ve Tutumlarının Belirlenmesi: Osmaneli İlçe Merkezi Örneği
}

\author{
Determination of Local People's Perceptions and Attitudes Protection of \\ Cultural Heritage and Use of Tourism Purpose: Case of Centre of Osmaneli \\ District
}

\author{
Ayşe Okuyucu', Mehmet Somuncu ${ }^{2}$ \\ ${ }^{1}$ Bilecik Şeyh Edebali Üniversitesi, Fen-Edebiyat Fakültesi, Coğrafya Bölümü, Bilecik. \\ ${ }^{2}$ Ankara Üniversitesi Dil ve Tarih-Coğrafya Fakültesi, Coğrafya Bölümü, Ankara.
}

\begin{abstract}
Özet: Kültürel mirasın korunması ve turizm amaçlı kullanılması konusunda yapılan çalışmalarda yerel halkın desteği oldukça önemlidir. Çünkü kültür ve miras alanlarında yaşayan yerel halk, buradaki kültürel mirasın doğrudan kullanıcıları oldukları gibi kültürel mirası sürdüren ve yaşatan kişilerdir. Bu çalışmada Osmaneli ilçe merkezinde yaşayan yerel halkın, kültürel miras, kültürel mirasin korunması ve turizm amaçlı kullanılması konularındaki algı ve tutumlarının belirlenmesi hedeflenmiştir. Araştırma alanı olarak Osmaneli ilçe merkezinin seçilmesinde buradaki kültürel mirasın varlı̆̆ fakat koruma konusunda yeterince çalışma yapılmamış olması etkili olmuştur. Çalışmada yerel halkın konu hakkındaki görüşlerini değerlendirmek üzere 193 kişiye yüz yüze görüssme tekniği ile 25 Ağustos-5 Ekim 2011 tarihleri arasinda 25 kapalı uçlu sorudan oluşan bir anket uygulanmıştır. Veriler SPSS paket programında analiz edilmiştir. Yerel halkın koruma ve turizme ilişkin tutum düzeyleri; cinsiyet, yaş gruplar, ikamet süresi, eğitim düzeyi, meslek ve gelir durumu bağımsız değişkenleri ile karşılaştırılmıştır. Karşılaştırmalarda Mann Whitney U testi, Kruskal Wallis H testi, t testi ve tek yönlü varyans analizi (ANOVA) kullanılmıştır. Araştırma sonuçlarına göre; yerel halk alandaki kültürel mirasın korunması konusunda olumlu görüşe sahiptir. Bunun yanında yerel halk, turizmin gelişmesine karşı olumlu tutuma sahiptir ve turizm işlerine katılma konusunda isteklidir.

Anahtar Kelimeler: Kültürel miras, kültürel mirasın korunması, turizm, yerel halk, turizmin etkileri, Osmaneli
\end{abstract}

Abstract: Protection of cultural heritage and using it tourism purposes; the support of local people are quite important. Because local people are living in the culture and heritage areas; direct users of heritage and experience of the individuals. In this study we aimed to determine the local people perception and attitudes about tourism and heritage conservation living in Osmaneli district. Existence of the cultural heritage and insufficient protection study are important to determine research area as Osmaneli. To measure of perceptions of local peoples a questionnaire was applied 193 people face-to-face interviews among 25 August-5 October 2011; 25 closed-ended questions were asked. The data was analyzed using the SPSS package. Local people's attitudes are evaluated in relation to independent variables of gender, age group, inhabitancy, education level, occupation, income level. For this purpose Mann Whitney U test, Kruskal Wallis $H$ test, $t$-test and one-way variance analysis (ANOVA) were used. According to the research results; the local people in the field have positive opinion cultural heritage protection with tourism. Besides the local people willing about joining the tourism affairs.

Keywords: Cultural heritage, protection of cultural heritage, tourism, local people, effects of tourism, Osmaneli 


\section{Giriş}

Son yıllarda iç ve dış turizmde farklı kültürleri tecrübe etme ve öğrenme amacı ile yapılan seyahatler artmıştır. Kültürel turizm tarihi yerlerin ve arkeolojik alanların ziyaret edilmesini, yerel toplumların festivallerine katılmayı, geleneksel dans ve törenlerin izlenmesini, yörelere özgü geleneksel ürünlerin alışverişini kapsamaktadır (Besculides vd., 2002). Çalışmalar turizmin bu şeklinin yerel halka, onların kültürlerine ve yanı sıra ziyaretçi toplumlara faydalar sağlayabildiğini göstermektedir (Besculides vd., 2002). Kültürel turizm aynı zamanda küçük toplumların kültürlerinin karakterlerini negatif etkileyebilecek potansiyele sahiptir. Bir yerin kültürünü yaşamaları için turistlere sağlanan firsatlar ev sahibi toplum için pozitif ve negatif sonuçlara yol açabilir. Turizm yönetiminde çıkar temelli yaklaşımlar ev sahibi toplum için hem fayda sağlayabilir hem de zarara yol açabilir.

Kültür ve miras turizmi, turizmin en hızlı gelişen ve en önemli bileşenlerinden biri olarak kabul edilmektedir (Poria vd., 2003). Miras turizminin gelişmesinde ana odak noktalar; yerel ekonomileri canlandırma, ev sahibi toplumun yaşam standartlarını arttırma, destinasyona turistleri çekebilmek, miras hakkındaki bilgileri yaymak ve kültürel mirasın yıkımlara karşı korunmasını sağlamaktır (Binoy, 2011). Bu nedenle miras turizmi genel turizm kapsamında ideolojik ve kurumsal kapsam bakımından farklıdır (Garrod ve Fyall, 2000).

Turizmin etkisi genellikle üç kategoriye ayrllır. Birincisi ekonomik etki, vergi gelirleri, artan iş imkânları, ek gelir, vergi yükü, enflasyon ve yerel kamu borcu gibi unsurları kapsar. İkincisi sosyokültürel etkidir ki; geleneksel el sanatları ve törenler, kültürlerarası iletişim ve hoşgörünün artması, suç oranının artması ve değişen kültürel gelenekleri kapsar. Üçüncüsü çevresel bakımdan yaşanan etkilerdir; parklar ve yaban hayatının korunması, kalabalık, hava, su, gürültü kirliliği, vahşi yıkım, vandalizm ve çöp sorunu gibi unsurları kapsar (Andereck vd., 2005).

Turizm genellikle doğal ve kültürel anlamda hassas alanlarda gelişmektedir. Bu nedenle yerel halkın turizme karşı tutum ve düşüncelerinde çevresel değerler ile ekonomik gelişimin birbirine bağımlı olduğu göz önünde bulundurulmalıdır (Varnacı Uzun ve Somuncu, 2011). Bir başka ifade ile yerel halk turizmin gelişmeye başladığı ilk dönemlerde, ekonomik faydaları ön planda tutmaktadır. Ancak turizm faaliyetlerinin iyi planlanmadığı alanlarda, faaliyetlerin artmasıyla sosyo-kültürel ve çevresel anlamda yaşanan bozulmalar, yerel halkın turizm için olumsuz düşünmesine yol açmaktadır.

Turizm yerel toplumların ekonomik çeşitliliklerini artırmada başlıca endüstri olarak tanımlanmaktadır. Fakat turizm ekonomik gerilemenin önüne geçmek için genel çare değildir. Turizm olumlu ve olumsuz etkiler yaratabilme potansiyeline sahiptir. Turizmde başarının sağlanabilmesi için onun güvenilir bir şekilde planlanması ve yönetilmesi gerekir (Byrd vd., 2009).

Kültür zengini destinasyonlar için bu alternatif ekonomik fırsat, kültürel mirasın bozulması bakımından potansiyel bir tehdit ürünü olabilir. Bu nedenle toplumlar böyle kaynaklardan ve turizmin faydalarından yoksun bırakılmaktadır. Miras turizmi koruma amaçlarını çeşitli çıkarlar için riske attığından, miras ve turizm arasındaki ilişki genellikle korumacı algı için çelişkilerle dolu ve çatışmalı olarak karakterize edilir. Bu tehditlerini azaltmak için farklı paydaşlar arasında iletişim, iş birliği ve uyuma ihtiyaç vardır (Aas vd., 2005). Bir toplumda kültür ve miras turizmin gelişmesinde kilit nokta paydaşların buna dahil edilmesidir. Toplum içinde paydaş desteği olmadan kültür ve miras turizmini geliştirmek neredeyse imkânsızdır.

Paydaş, bir organizasyonun hedeflerinin başarılmasında etkilenen ya da etkileyen birey ya da gruplardır. Paydaş grupları ve onların çıkarlarının araştıılması turizm literatüründe yinelenen bir tema olmuştur (Byrd vd., 2009). Paydaşlar ve onların turizm gelişmesindeki rolü hakkındaki turizm konsepti iş yönetimi ve kamu idaresi literatürleri üzerine temellendirilmiştir. Genel olarak turizmde dört ana paydaş vardır: turistler, yerel halk, girişimciler ve yerel hükümet yetkilileri (Byrd vd., 2009). Çeşitli paydaşlar turizm planlama sürecinde önemlidirler. Paydaşlar arasındaki işbirliği ve uyum planlanan alan için başlıca meseledir (Aas vd., 2005). Paydaşlar arasında yerel halk, turizmin geliştiği 
alanlardaki en önemli paydaş konumundadır. Yerel halkı turizm gelişim sürecine dâhil etmek, bu konudaki görüş ve önerilerini almak, fikir alışverişinde bulunmak ve gelecekteki turizm gelişmesini teşvik yönünde karşılıklı fikir alışverişi yapmak, yerel halkın karar merkezlerini etkileyebilmesi ve kendilerini turizmin bir parçası olarak hissetmeleri açısından oldukça önemlidir (Varnacı Uzun ve Somuncu, 2011). Zira turizm gelişmesinde yerel halkın desteğinin önemi geniş̧ ölçüde kabul edilmiş̧tir ve bu konu giderek artan bir araştırma alanı olmaya başlamıştır.

Yerel halkın turizm konusundaki tepkileri çeşitli nedenlerden önemlidir. Bu en azından ev sahibi toplumların yaşam kalitesi bakımından önem arz etmektedir. Sadece kar amacı güden turizm faaliyetleri sonucunda yaşanan olumsuzluklar, yerel halkın, turizm gelişmelerini riske atmasına, zarar vermesine ya da sonlandırmasına yol açabilir. Ancak yerel halkın bu konulardaki tepkilerinin önceden ölçülmesi turizm plancılarına yardım edebilir. Eğer yerel halkın turizm endüstrisini niçin desteklediği ya da karşı çıktığı bilinirse, olumsuz sosyal etkiler minimize edilebilir ve bu konudaki alternatifler arttırılabilir. Bunun gibi yerel halkın yaşam kalitesinin arttırılabilmesi, toplumun turizmin olumsuz etkilerinden korunmasını sağlar (Williams ve Lawson, 2001).

Çeşitli çalışmalarda elde edilen bulgularda, yerel halkın turizme karşı tutumları; sosyodemografik özellikler, turizme ekonomik bağlılık, miras çekiciliklerine olan fiziksel yakınlık, geleneksel kültürel alanlara bağlılık gibi çeşitli durumlara bağlı olduğu elde edilmiş̧tir (Uriely vd., 2001).

Osmaneli ilçe merkezi sahip olduğu geleneksel ve anıtsal yapılar ile diğer somut olmayan miras özellikler bakımından yerel yönetimlerin turizmi geliştirmeyi arzu ettikleri ve çeşitli girişimlerin olduğu bir alandır. Bu nedenle çalışmada, kültür ve miras turizmi faaliyetlerinin henüz yoğunluk kazanmadığı, ancak bu yönde potansiyele sahip olan Bilecik'e bağlı Osmaneli ilçe merkezinde yürütülmüştür. Çalışmada kültürel mirasın korunması ve turizm amaçlı kullanıma kazandırılması konusunda yerel halkın görüşlerinin alınması amaçlanmıştır. Böylece kendi bölgelerini en iyi tanıyan yerel halkın kültürel mirasın korunması ve yönetilmesi için bilgi sağlayacağı, yerel halkın yaşam alanları için düşünülen koruma ve turizm faaliyetleri konusunda başlangıçtan itibaren etkili olacağı, ilçe merkezinin kültür ve miras özelliklerine uygun turizm anlayışının geliştirileceği düşünülmüştür.

\section{Araştırma Alanı}

Osmaneli ilçesi Türkiye'nin coğrafi bölge sistematiği içinde Marmara Bölgesi’nin Güney Marmara Bölümü’nde Bilecik ili sınırları içinde yer almaktadır. Osmaneli ilçesini; kuzeydoğudan Sakarya'nın Pamukova ve Geyve ilçeleri; batıdan Bursa'nın Yenişehir ve İznik ilçeleri; güneyden Bilecik ve Bilecik'in Gölpazarı ilçeleri çevrelemektedir (Şekil 1). 


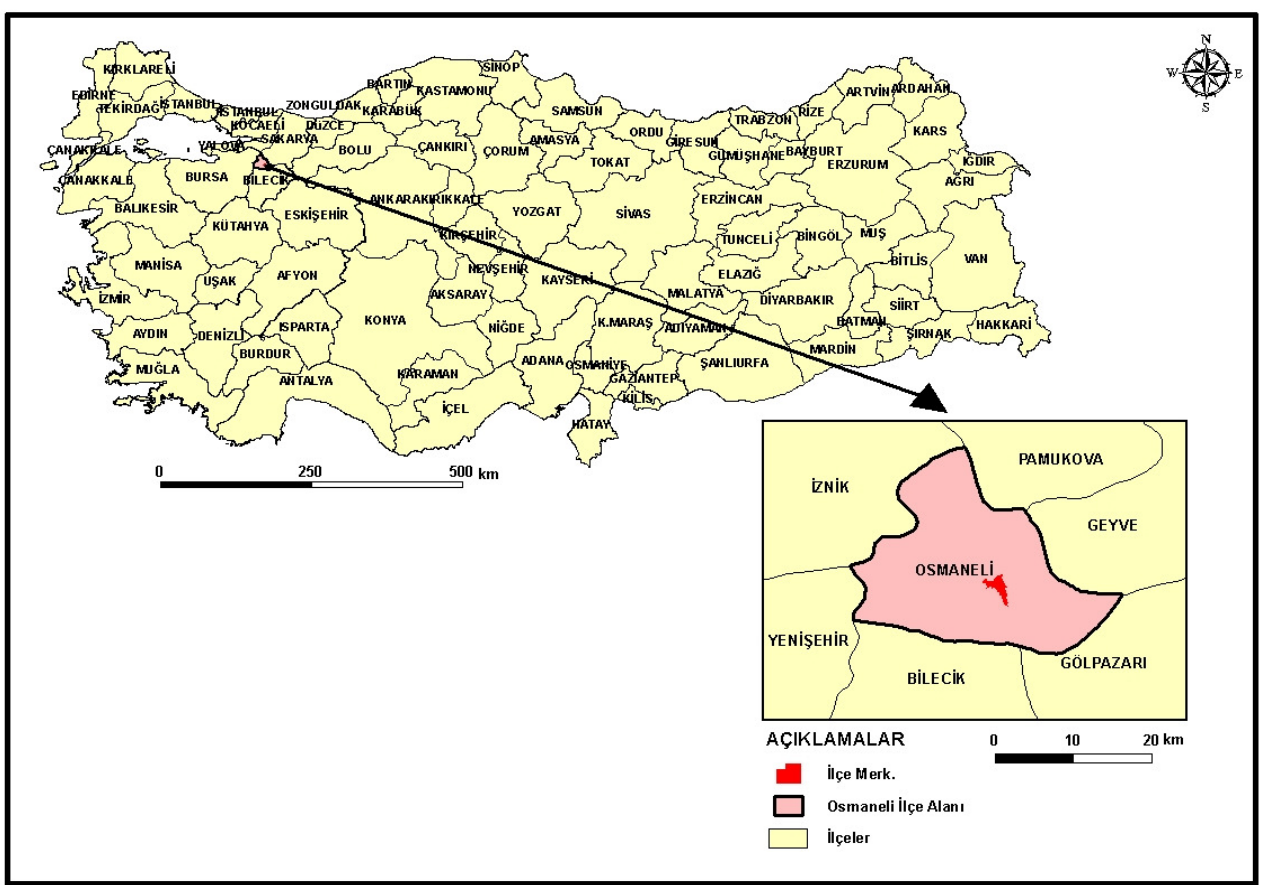

Şekil 1. Osmaneli İlçesi lokasyon haritası

İlçe, merkez ve 27 köy dâhil toplam $526 \mathrm{~km}^{2}$ lik bir alana sahiptir. Araştırma konusunun kapsamı ve sınırları nedeniyle bu sahanın tamamı çalışma kapsamında değildir. Araştırmada kültürel mirasın yoğun olduğu Camiicedid, Camiikebir mahallelerinde kentsel sit alanı olarak ilan edilen bölgede yoğunlaşılmıştır (Şekil 2).

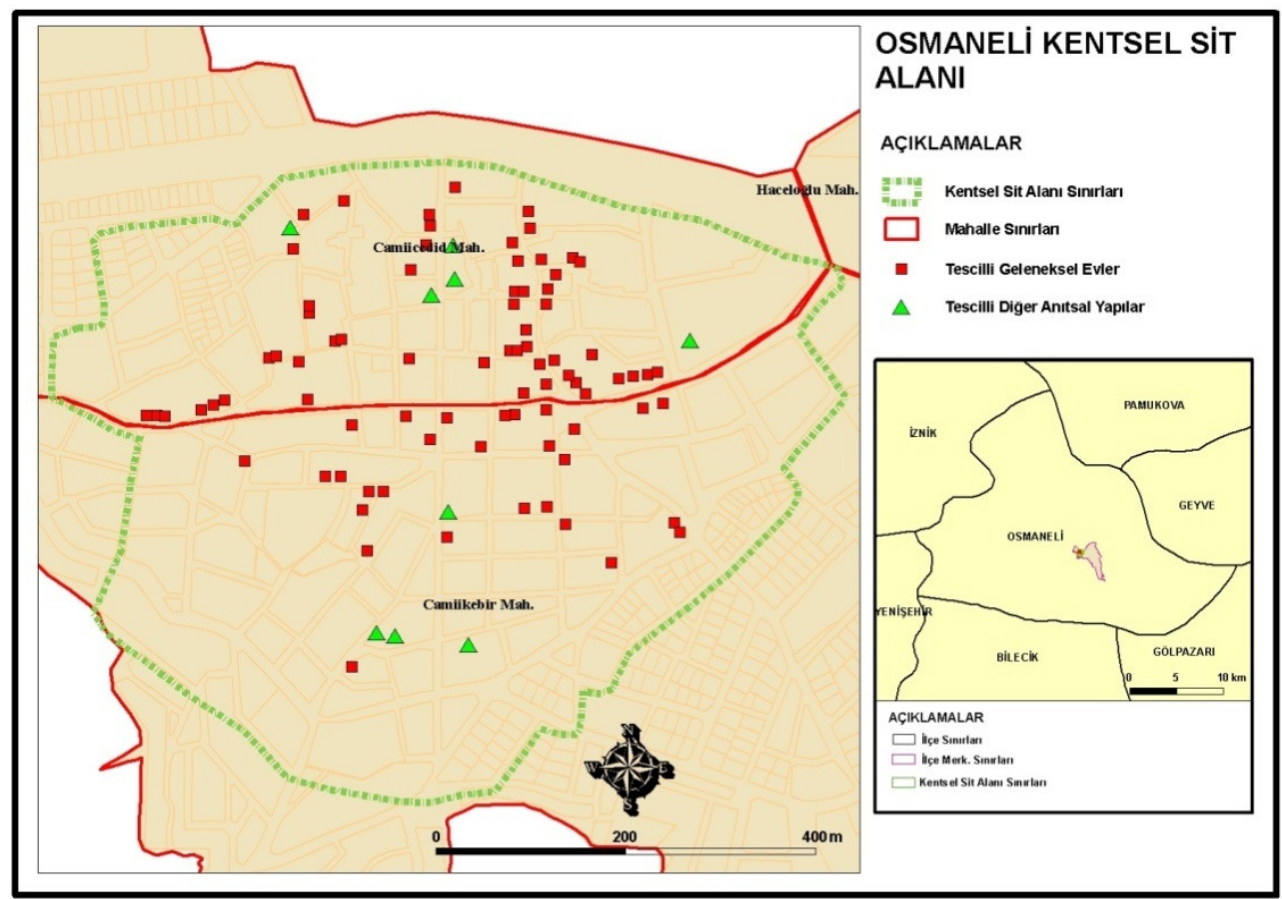

Şekil 2. Osmaneli kentsel sit alanı 
İlk adı Leuke veya Leukai (Beyaz şehir) olan Osmaneli, antik çağda Bithynia bölgesinde bir köydü (Özgür, 1990). İlçe sınırları içinde bulunan höyükler ve bazı kalıntılar, bölgede ilk yerleşimin M.Ö. 2000'lere kadar uzandığını göstermektedir (Uluengin ve Saatçi, 2009). Bölgede çeşitli dönemlerde Helen, Trak, Bitinya, Roma, Bizans, Selçuklu ve Osmanlı gibi birbirini izleyen uygarlıklar hüküm sürmüştür. İlçe M.Ö 1200'lerde, Friglerin, Perslerin daha sonra da Romalıların egemenliğine girmiş; 1308 yılında Osman Gazi tarafından Osmanlı topraklarına katılmıştır (Anonim, 2006). Buna göre; Osmaneli ilçe merkezinde yerleşmenin tarihi çok eskilere dayanmaktadır.

Günümüzde ise Osmaneli ilçe merkezinde 200 kadar geleneksel ev bulunmaktadır. Özellikle 17. yüzyılda yörenin başlıca geçim kaynağı olan ipek böcekçiliği ve kozacılık faaliyetlerine göre şekillenmiş bu evler, sahip oldukları mimari özellikleri ile oldukça dikkat çekicidir (Okuyucu, 2011), (Şekil 3).

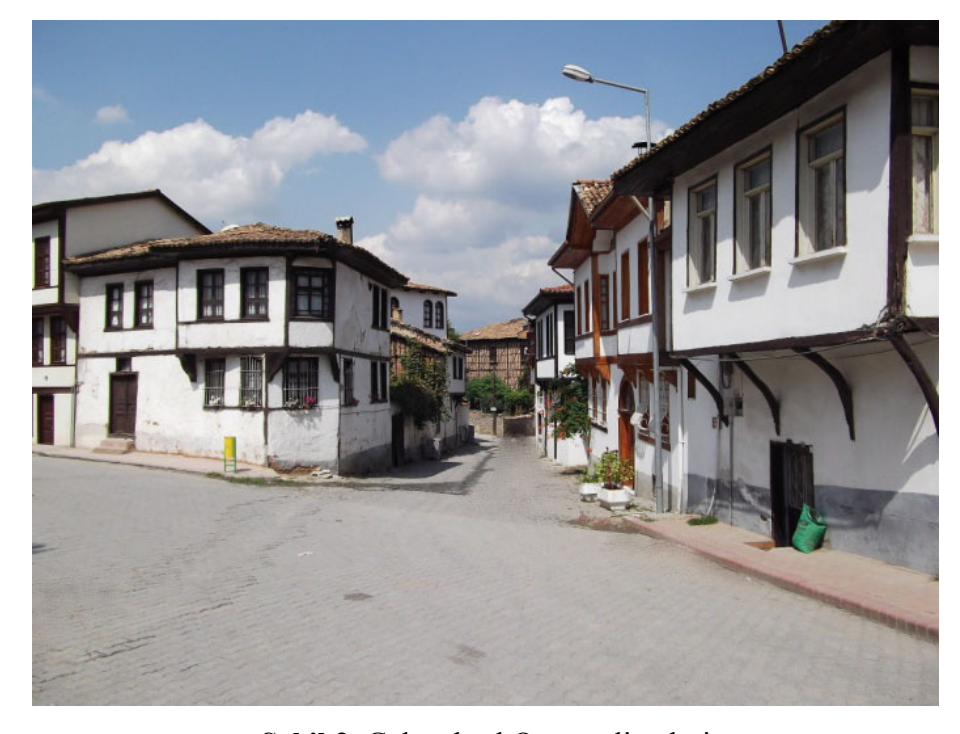

Şekil 3. Geleneksel Osmaneli evleri

$\mathrm{Bu}$ evlerden 90 tanesi Eski Eserler ve Müzeler Genel Müdürlüğ̈’nce tescillenerek koruma altına alınmıştır. Ancak yapılan arazi çalışmaları sırasında tescil kayıtlarında olmasına rağmen, bu evlerden 9 tanesinin yangın vb. çeşitli sebeplerden yok olduğu tespit edilmiştir. Buna göre 2003 yılında kentsel sit alanı ilan edilen alanda; 81 tane tescilli geleneksel Osmaneli evi, dört adet dini yap1, hükümet konağı, tarihi çeşme, hamam, eski şehir hanı ve eski ilkokul olmak üzere toplam 90 adet tescilli yapı bulunmaktadır (Şekil 2). Bu değerlere ek olarak yöredeki el sanatları, yöresel mutfak, dille birlikte sözlü gelenek ve anlatımlar, korunması gerekli somut olmayan kültürel miras öğelerindendir.

\section{Materyal ve Yöntem}

İlçe merkezindeki kültürel mirasın envanter tespiti ve ilçe merkezinde kültürel mirasın dağılışının haritalanması için 1/1000 ölçekli kent planı, imar planı ve koruma amaçlı imar planları alınmış ve bu haritalar coğrafi bilgi sistemleri tabanlı bir yazılım olan ArcGIS 9.3 programı ile amaca uygun olarak çizilerek yeniden düzenlenmiştir.

Osmaneli ilçe merkezinde yaşayan yerel halkın, kültürel mirasın korunması konusundaki görüşleri ve kültürel mirasın turizmde kullanılması konusuna ne ölçüde hazır olduğunun belirlenmesi araştırmanın en önemli konulardan birisidir. Çünkü turizm; ekonomik, toplumsal-kültürel ve çevre ile ilgili konularda olumlu ve olumsuz etkilerde bulunmaktadır. Turizmin olumlu ya da olumsuz etkilerinden öncelikle etkilenecek olan kişiler turizm bölgelerinde yaşayan yerel halktır. Bu nedenle araştırmada Osmaneli ilçe merkezinde yaşayan yerel halka turizm ve koruma konusundaki algı ve 
tutumlarını ölçmek üzere bir anket çalışması yapılmıştır. Buna göre; \%95 güven düzeyinde 0.07 örnekleme hatası ile örneklem büyüklügü (n) 193 kişi olarak belirlenmiştir.

Ankette olasılıklı örnekleme türü kullanılmıştır. Olasılıklı örneklemede her bireyin örnekleme dâhil olma olasılığı eşittir. Bu eşitliği sağlamak için seçim tesadüfi olarak yapılmıştır. Anket uygulaması 25 Ağustos-5 Ekim 2011 tarihleri arasında Osmaneli ilçe merkezinde yüz yüze görüşme tekniği ile yapılmıştır. Anket kapalı uçlu 25 sorudan oluşmaktadır. Üç bölümden oluşan anketin ilk bölümü kişisel bilgileri, ikinci bölümü ilçe merkezinde yaşayan yerel halkın buradaki kültürel mirasın korunması konusundaki düşünceleri, üçüncü bölümü ise yerel halkın ilçe merkezindeki kültürel mirasın turizm amaçlı kullanılması konusundaki düşüncelerini ölçmeye yöneliktir.

Verilerin analiz edilmesinde SPSS 17 (Statistical Package for the Social Sciences) programından yararlanılmıştır. Araştırmada ilk olarak yerel halkın demografik bilgileri frekans tabloları aracıllğıyla analiz edilmiştir. Bununla birlikte yerel halkın kültürel miras, kültürel mirasın korunması ve turizm konusundaki düşünceleri yine frekans tabloları aracılığı ile verilmiştir. Çalışmada ayrıca yerel halkın Osmaneli ilçe merkezindeki ikamet süresi ile turizme bakış açıları; cinsiyet ve turizme destek verme arasında anlamlı bir fark olup olmadığı karşılaştııılmıştır. Karşılaştırmalarda sırasıyla tek yönlü varyans analizi (ANOVA) ve t testi kullanılmıştır. Son olarak yerel halkın ilçe merkezinde turizmi destekleme konusundaki görüşleri analiz edilmiştir. Bu kısımda yerel halkın turizmde yapabileceklerini belirttikleri işleri daha net bir şekilde ortaya koyabilmek amaciyla yerel halkın demografik özellikleri ile karşılaştırmalar yapılmıştır. Elde edilen veriler normal dağılım durumu sağlamadığından bu kısımda, turizmde yapılabilecek işlerin ve demografik özelliklerin karşılaştırılmasında Mann-Whitney $U$ testi ve Kruskal-Wallis $H$ testi kullanılmıştır. Bağımlı değişkenlerin iki seçenekli bağımsız değişken arasında anlamlı bir farklılık gösterip göstermediğine bakılmak istendiğinde uygulanacak olan test parametrik olmayan Mann-Whitney U testi ve ikinden fazla seçenekli bağımsız değişken arasında anlamlı bir farklılık gösterip göstermediğine bakılmak istendiğinde uygulanacak olan test ise parametrik olmayan Kruskal-Wallis $\mathrm{H}$ testi olduğundan, bu iki test kullanılmıştır. İstatistiksel anlamlılık sınırı olarak $\mathrm{p}<0.05$ kabul edilmiş, elde edilen bilgiler tablolar aracılığıyla açıklanmış ve yorumlanmıştır (Bayram, 2011). Buna göre yerel halkın cinsiyet, yaş, eğitim düzeyi, ilçe merkezinde yaşama süresi, geçim tipi ve aylık gelir özellikleri ile yerel halkın turizmde yapabilecekleri işlerle ilgili sorulara verilen kapalı uçlu cevaplar arasında anlamlı bir fark olup olmadığı analiz edilmiştir.

\section{Bulgular}

\subsection{Ankete Katılan Yerel Halkın Sosyo-Ekonomik Yapıs1}

Ankete katılan bireylerin $\% 43.5$ 'i bayanlar, $\% 56.5$ 'i erkeklerden oluşmaktadır. Yaş gruplarına göre dağılıma bakıldığında ise ilk sırada \%33.2 ile 26-35 yaş arasındaki bireyler yer almaktadır. Ankete katılan bireyler arasında \%38.3 ile lise mezunları birinci sıradadır. Geçim tipine göre dağılımda ise \%32.1 ile memurların ilk sırada, \%25.4 ile işçilerin ikinci sırada yer aldığı görülmektedir. Ankete katılan bireylerin \%45.6'sı aylık 750-1500 TL arasında gelire sahiptir (Çizelge $1)$. 
Çizelge 1. Ankete katılan bireylerin demografik özellikleri

\begin{tabular}{|c|c|c|}
\hline Cinsiyet & Frekans (n) & $\%$ \\
\hline Kadın & 84 & 43,5 \\
\hline Erkek & 109 & 56,5 \\
\hline Toplam & 193 & 100.0 \\
\hline Yaş grupları & Frekans (n) & $\%$ \\
\hline $18-25$ & 37 & 19.2 \\
\hline $26-35$ & 64 & 33.2 \\
\hline $36-45$ & 46 & 23.8 \\
\hline $46-55$ & 33 & 17.1 \\
\hline $55-65$ & 10 & 5.2 \\
\hline $65+$ & 3 & 1.6 \\
\hline Toplam & 193 & 100.0 \\
\hline Eğitim düzeyi & Frekans (n) & $\%$ \\
\hline Okuma-yazma bilen & 6 & 3.1 \\
\hline İlkokul & 30 & 15.5 \\
\hline İlköğretim & 15 & 7.8 \\
\hline Lise & 74 & 38.3 \\
\hline Yüksek okul & 30 & 15.5 \\
\hline Üniversite & 32 & 16.6 \\
\hline Yüksek lisans & 5 & 2.6 \\
\hline Doktora & 1 & 0.5 \\
\hline Toplam & 193 & 100.0 \\
\hline Geçim tipi & Frekans (n) & $\%$ \\
\hline Memur & 62 & 32.1 \\
\hline İşçilik & 49 & 25.4 \\
\hline Esnaf-ticaret & 27 & 14.0 \\
\hline Diğer & 23 & 11.9 \\
\hline Emekli & 19 & 9.8 \\
\hline Çiftçilik & 11 & 5.7 \\
\hline Hayvancılık & 2 & 1.0 \\
\hline Toplam & 193 & 100.0 \\
\hline Aylık gelir durumu & Frekans (n) & $\%$ \\
\hline 750 TL'den az & 38 & 19.7 \\
\hline $750-1500 \mathrm{TL}$ & 88 & 45.6 \\
\hline $1501-2000 \mathrm{TL}$ & 37 & 19.2 \\
\hline 2000 TL'den fazla & 20 & 10.4 \\
\hline Belirtmemiş & 10 & 5.2 \\
\hline Toplam & 193 & 100,0 \\
\hline
\end{tabular}

Birçok çalışma bölgede yerleşik olarak yaşama süresinin turizmin etkisinin algılamasını etkilediğini ortaya koymaktadır (Akova, 2006). Toplumdaki insanların ikamet ettikleri süre ne kadar uzun ise turizme yönelik tutumlarının, o derece olumsuz olduğunu ileri sürülmektedir. Bununla birlikte yaşam süresinin turizmi algılamaya etkisiyle ilgili birbirine tezat düşen bulgular da bulunmaktadır. Bölgede yaşam süresinin yüksek olmasının hem olumlu hem de olumsuz yüksek oranda korelasyon oluşturduğunu belirtilmektedir (Akova, 2006). Ankete katılan bireylerin \% 51.8'inin 20 ylldan fazla süredir Osmaneli ilçe merkezinde ikamet ettikleri tespit edilmiştir (Çizelge 2).

Çizelge 2. Yerel halkın Osmaneli ilçe merkezinde ikamet süresi

\begin{tabular}{|l|c|c|}
\hline İkamet süresi & Birey say1s1 (n) & $\%$ \\
\hline 1 y1ldan az & 13 & 6.7 \\
\hline $1-5$ y1l aras1 & 26 & 13.5 \\
\hline $6-10$ y1l aras1 & 16 & 8.3 \\
\hline $11-15$ y1 aras1 & 21 & 10.9 \\
\hline $16-20$ y1l aras1 & 17 & 8.8 \\
\hline 20 y1ldan fazla & 100 & 51.8 \\
\hline Toplam & 193 & 100.0 \\
\hline
\end{tabular}


Buna göre çalışmada ikamet süresine göre turizme bakış açısının anlamlı bir farklılık gösterip göstermediğini test etmek amacıyla bağımsız örneklem tek yönlü varyans analizi (ANOVA) uygulanmıştır. Yerel halkın ikamet süresine göre değerlendirme incelendiğinde; en yüksek tutuma 1 yıldan daha az ikamet eden yerel halkın $(\bar{X}=1,0769)$ sahip olduğu görülmektedir (Çizelge 3 ).

Çizelge 3. Yerel halkın ikamet süresi gruplarına göre, turizme bakış açılarına ilişkin tutum puanlarına ait betimsel istatistikler

\begin{tabular}{|l|l|c|c|c|}
\hline Bağımlı değişken & \multicolumn{1}{|c|}{ İkamet süresi } & $\mathrm{N}$ & $\bar{x}$ & $\mathrm{SS}$ \\
\hline \multirow{4}{*}{$\begin{array}{l}\text { Yerel halkın } \\
\text { turizme bakış açıs1 }\end{array}$} & 1 yıldan az & 13 & 1,0769 & 0,27735 \\
\cline { 2 - 5 } & $1-5$ y1l aras1 & 26 & 1,0000 & 0,00000 \\
\cline { 2 - 5 } & $6-10$ yıl aras1 & 16 & 1,0000 & 0,00000 \\
\cline { 2 - 5 } & $11-15$ yıl aras1 & 21 & 1,0000 & 0,00000 \\
\cline { 2 - 5 } & $16-20$ y1l aras1 & 17 & 1,0000 & 0,00000 \\
\cline { 2 - 5 } & 20 yıldan fazla & 100 & 1,0100 & 0,10000 \\
\cline { 2 - 5 } & Toplam & 193 & 1,0104 & 0,10153 \\
\hline
\end{tabular}

ANOVA sonuçlarına göre ise; ikamet süresine göre turizme bakış açılarındaki fark istatistiksel olarak anlamlı değildir ( $>0.05$ ), (Çizelge 4). Buna göre; ikamet süresi bağımsız değişkeni turizme bakış açısına ilişkin tutumları etkilememektedir.

Çizelge 4. İkamet süresi ve turizme bakış açısı iliş̧in tutum puanlarına ait ANOVA sonuçları

\begin{tabular}{|l|c|c|c|c|c|}
\hline & Kareler toplamı & $\begin{array}{c}\text { Serbestlik } \\
\text { derecesi }\end{array}$ & $\begin{array}{c}\text { Karelerin } \\
\text { ortalamas1 }\end{array}$ & F & Anlamlılik (p) \\
\hline Gruplar aras1 & 0,066 & 5 & 0,013 & \multirow{2}{*}{1,294} & \multirow{2}{*}{0,268} \\
\cline { 1 - 4 } Grup içi & 1,913 & 187 & 0,010 & & \\
\hline Toplam & 1,979 & 192 & & & \\
\hline
\end{tabular}

\subsection{Yerel Halkın Kültürel Miras, Kültürel Mirasın Korunması ve Turizm Konusundaki Algıları}

Bu bölümde yerel halkın Osmaneli kentsel sit alanındaki kültürel miras ve kültürel mirasın korunması konusundaki görüşleri değerlendirilecektir. Kültürel mirasın somut ve somut olmayan miras olmak üzere iki boyutu vardır. Yerel halka yöneltilen "Sizce kültürel miras neleri kapsar?" sorusu, ankete katılan yerel halkın gerek somut, gerek somut olmayan kültürel mirası algılama düzeylerini ölçmeye yöneliktir. Ankete katılan yerel halk en çok \% 89.6 ile geleneksel evlerin, ardından \% 60.1 ile anıtsal yapıların kültürel miras kapsamına girdiğini belirtmiştir. Ayrıca yöresel yemekler \% 58.5, gelenek ve görenekler \% 55.4 ve el sanatları $\% 47.7$ gibi somut olmayan kültürel miras öğeleri de, somut kültürel miras öğelerinden çok düşük olmayacak düzeyde onları takip etmiştir (Çizelge 5). Bu da yerel halkın hem somut hem de somut olmayan kültürel miras öğelerinin bilincinde olduğunu göstermektedir.

Çizelge 5. Ankete katılan yerel halkın kültürel miras algısı

\begin{tabular}{|l|c|c|}
\hline Kültürel miras & Birey sayısı (n) & $\%$ \\
\hline Geleneksel evler & 173 & 89.6 \\
\hline Anıtsal yapılar & 116 & 60.1 \\
\hline Yöresel yemekler & 113 & 58.5 \\
\hline Gelenek ve görenekler & 107 & 55.4 \\
\hline El sanatları & 92 & 47.7 \\
\hline Diğer & 9 & 4.7 \\
\hline
\end{tabular}

Ankete katılan yerel halkın \% 82.9'u Osmaneli ilçe merkezinde kültürel mirasın yeterince korunamadığı; buna karşın \% 17.1'i yeterince korunduğu görüşündedir (Şekil 4). Günümüzde kültürel mirasın korunmasında, koruma kullanma yaklaşımı ile birlikte turizmin önemi artmıştır. Turizmin 
geliştiği alanlarda ekonomik gelişim ve hayat kalitesinin artması yanında kültürel mirasın ya da doğal alanların korunması konusunda da büyük bir potansiyel olmaktadır.

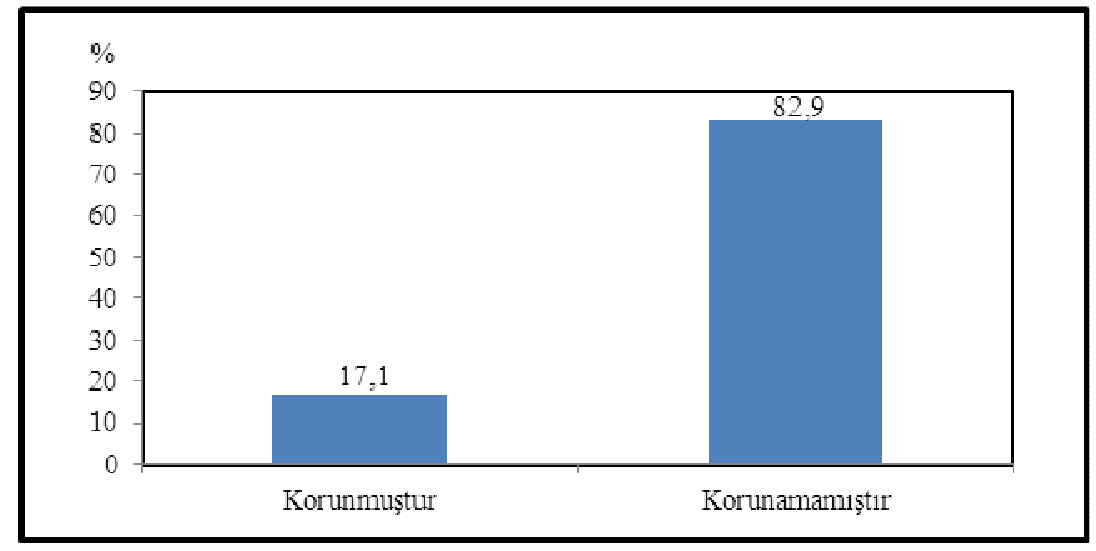

Şekil 4. Ankete katılan yerel halkın kültürel mirasın korunmuşluk durumu konusundaki görüşleri

Osmaneli ilçe merkezinde de turizm; kültürel mirasın korunması konusunda ve ekonomik anlamda firsatlar sunabilir. $\mathrm{Bu}$ nedenle ilçe merkezinin sahip olduğu potansiyelin harekete geçirilebilmesi önem taşımaktadır. Turizmin gelişiminden doğrudan olumlu ya da olumsuz olarak etkilenecek olan yerel halkın turizme katılması da bölgedeki turizm faaliyetlerinin gelişmesini olumlu etkiler (Özdemir ve Kervankıran, 2011). Bu nedenle Osmaneli'nde yerel halkın turizmi desteklemesi, ilçe merkezinde turizmin gelişmesi için olumlu bir durumdur. Ankete katılan yerel halkın \% 99'u Osmaneli ilçe merkezinde turizmin gelişmesini olumlu karşılayacağını, \% 1'i olumsuz karşılayacağını belirtmiştir (Çizelge 6).

Çizelge 6. Ankete katılan yerel halkın Osmaneli ilçe merkezinde turizmin gelişmesi konusuna bakış açısı

\begin{tabular}{|l|c|c|}
\hline Turizme bakış açısı & Birey sayısı (n) & $\%$ \\
\hline Olumlu & 191 & 99 \\
\hline Olumsuz & 2 & 1 \\
\hline Toplam & 193 & 100.0 \\
\hline
\end{tabular}

Turizm uzun bir süre ekonomik gelişimi hızlandırıcı bir araç olarak görülmüştür. Bu konuda yapılan ilk çalışmalar turizm gelişiminin yerel halka ekonomik etkileri üzerine olmuştur (Akova, 2006). Birçok çalışma ekonomik faydanın yerel halk tarafından en fazla önem verilen faktör olduğunu ortaya çıkarmıştır. Araştırmalar turizmin istihdamı artırdığını, yeni yatırım fırsatları yarattığını ve yerel halka ve yerel yönetimlere gelir sağladığını ortaya koymaktadır. Hemen hemen bütün çalışmalarda ekonomik fayda ve tutumlar arasında olumlu bir ilişki olduğu saptanmıştır (Akova, 2006). Ancak, başlangıç aşamasında turizm genellikle algılanan ekonomik faydadan dolayı yerel halkın bir kısmı tarafından büyük bir istekle karşılanırken fiziki çevrede meydana gelen istenmeyen değişimler ve turistlerin geliş nedenleri değiş̧ikçe bu olumlu his aşama aşama olumsuza dönüşebilmektedir (Akova, 2006). Turizm faaliyetlerinin henüz yoğunluk kazanmadığı Osmaneli ilçe merkezinde de yerel halk ekonomik faydadan dolayı turizmi büyük bir istekle karşılamaktadır. $\mathrm{Bu}$ nedenle turizmin gelişmesini olumlu karşlayan grubun turizmden beklentileri en çok, yerel halkın ekonomik gelirinin artması yönündedir (Çizelge 7). 
Çizelge 7. Turizmi olumlu karşıllayan yerel halkın turizmden beklentileri

\begin{tabular}{|l|c|c|}
\hline Beklentiler & Birey sayıs1 (n) & $\%$ \\
\hline Yerel halkın ekonomik gelirinin artmas1 & 151 & 78.2 \\
\hline Kültürel mirasın öneminin anlaşılması & 130 & 67.4 \\
\hline Yerel kültürün canlanması & 120 & 62.2 \\
\hline Altyapının iyileşmesi & 40 & 20.7 \\
\hline Diğer & 1 & 0.5 \\
\hline
\end{tabular}

Turizmin sosyo-kültürel bakımdan pozitif ve negatif gelişmeler ortaya çıkardığı bilinmektedir. Önemli sayıdaki araştırmacı, bu konuda turizmin zararlarından bahseder. Ancak kaynaklar başarılı bir şekilde planlandığında ve geliştirildiğinde turizmin çok sayıda negatif etkisi ortadan kalkar (Besculides vd., 2002). Örneğin turizm, turistlere yönelik hediyelik eşya talebini karşılamak için ya da ihracat için geleneksel el sanatlarının yeniden canlanmasını sağlar. Sürekli ziyaret edilen alanlarda restorasyon, rekonstrüksiyon vb. koruma faaliyetleri artar. Toplumsal kaynaşma ve hoşgörü artar, kültürel mirasın korunması için bir firsat yaratılmış olur.

Osmaneli ilçe merkezinde yerel halk turizmin ilçe merkezinde yaratacağı pozitif etki olarak ilk sırada \% 73.1 ile geleneksel evleri bakımlı ve modern bir görünüme kavuşturacağını, ardından $\% 65.3$ ile turizm sayesinde yerel halkın koruma bilincinin artacağını belirtmişlerdir (Çizelge 8). Bu nedenle Osmaneli'nde turizmin gelişmesi başlangıçta fiziki anlamda iyileştirmeler yapsa da, bu beraberinde somut olmayan kültürel mirasın tekrar canlanmasını sağlayabilir.

Çizelge 8. Turizmin Osmaneli ilçe merkezinde kültürel mirasın korunmasında yaratacağı düşünülen pozitif etki alanları

\begin{tabular}{|l|c|c|}
\hline Olumlu etki alanları & Birey sayısı (n) & $\%$ \\
\hline Geleneksel konutların görünümü & 141 & 73.1 \\
\hline Koruma bilincinin artması & 126 & 65.3 \\
\hline El sanatlarının tekrar canlanması & 79 & 40.9 \\
\hline Ciddi koruma önlemlerinin alınması & 77 & 39.9 \\
\hline Yöresel yemeklerin hatırlanması & 47 & 24.4 \\
\hline Diğer & 1 & 0.5 \\
\hline
\end{tabular}

Turizm planlamasının yapıldığı alanlarda yerel halkın turizme bakış açısı kadar yerel halkın turizme destek verip veremeyeceği konusu da oldukça önemli bir konudur. Ankete katılan yerel halkın \% 87.6'sı turizme destek verebileceklerini, \% 12.4'ü destek veremeyeceklerini belirtmişlerdir (Çizelge 9).

Çizelge 9. Anket katılan yerel halkın turizme destek verip-vermeme konusundaki görüşlerinin dağılımı

\begin{tabular}{|l|c|c|}
\hline Cevaplar & Birey sayıs (n) & $\%$ \\
\hline Evet, turizme destek verebilirim & 169 & 87.6 \\
\hline Hayır, turizme destek veremem & 24 & 12.4 \\
\hline Toplam & 193 & 100.0 \\
\hline
\end{tabular}

Çalışmada cinsiyete göre turizme destek verme durumları arasında istatistiksel olarak anlamlı bir fark olup olmadığı t-testi ile değerlendirilmiştir. Çeşitli uygulamalarda bu iki değişken arasındaki ilişki anlamlı ya da anlamlı değildir şeklinde çıkabilmektedir. Cinsiyet değişkenine göre yerel halkın turizme destek olmasına ilişkin tutum puanları karşılaştırıldığında kadınların ortalamaları $(\overline{\mathrm{X}}=1,1548)$, erkeklere göre $(\overline{\mathrm{X}}=1,1009)$ daha yüksektir. Ancak $\mathrm{t}$ testi sonuçlarına göre bu farklılık istatistiksel olarak anlamlı değildir ( $>00,05)$, (Çizelge 10).

Çizelge 10. Cinsiyetlerine göre yerel halkın turizme destek olmasına ilişkin tutum puanına ait t testi sonuçları

\begin{tabular}{|l|c|c|c|c|c|c|c|}
\hline Bağımlı değişken & Cinsiyet & $\mathrm{N}$ & $\bar{X}$ & $\mathrm{SS}$ & $\mathrm{Sd}$ & $\mathrm{t}$ & $\mathrm{p}$ \\
\hline $\begin{array}{l}\text { Yerel halkın turizme } \\
\text { olmasına ilişkin tutum }\end{array}$ & Kadın & 84 & 1,1548 & 0,36385 & \multirow{2}{*}{191} & $-1,122$ & 0,263 \\
\cline { 2 - 6 } & Erkek & 109 & 1,1009 & 0,30261 & \\
\hline \multirow{2}{*}{$<0,05$}
\end{tabular}


Araştırmada yerel halkın turizme katılma isteği yanında, turizme katılmaları halinde ne gibi işler yapabilecekleri de sorgulanmıştır. Bu amaçla yerel halka turizmde yapabilecekleri işler ile ilgili sorular yöneltilmiş̦tir. Yapılan değerlendirmeler sonucunda yerel halk, en çok el işi ürünler üretip pazarlayarak $(n=57)$, ardından turizm tesislerinde çalışarak $(n=50)$ turizme destek verebileceklerini belirtmişlerdir (Çizelge 11).

Çizelge 11. Turizme destek verebileceklerini belirten bireylerin verebilecekleri destek türlerinin dağılımı

\begin{tabular}{|l|c|c|c|c|c|c|}
\hline \multirow{2}{*}{ Destek türleri } & \multicolumn{2}{|c|}{ Evet } & \multicolumn{2}{c|}{ Hayır } & \multicolumn{2}{c|}{ Toplam } \\
\cline { 2 - 7 } & $\begin{array}{c}\text { Birey } \\
\text { sayıs1 } \\
(\mathrm{n})\end{array}$ & $\%$ & $\begin{array}{c}\text { Birey } \\
\text { say1s1 } \\
(\mathrm{n})\end{array}$ & $\%$ & $\begin{array}{c}\text { Birey } \\
\text { sayı1 } \\
(\mathrm{n})\end{array}$ & $\%$ \\
\hline El işi ürünler üretip turizmde pazarlarım & 57 & 29.5 & 136 & 70.5 & 193 & 100.0 \\
\hline Turizm tesislerinde çalışırım & 50 & 25.9 & 143 & 74.1 & 193 & 100.0 \\
\hline Tarımsal ürünlerimi pazarlarım & 38 & 19.7 & 155 & 80.3 & 193 & 100.0 \\
\hline Ev pansiyonculuğu yaparım & 36 & 18.7 & 157 & 81.3 & 193 & 100.0 \\
\hline Yöresel yemeklerimi pazarlarım & 36 & 18.7 & 157 & 81.3 & 193 & 100.0 \\
\hline Diğgr & 35 & 18.1 & 158 & 81.9 & 193 & 100.0 \\
\hline
\end{tabular}

Araştırmada son olarak yerel halkın demografik özelliklerine göre turizme katılmaları halinde yapabilecekleri işlere ilişkin isteklerinin istatistiksel olarak anlamlı farka sahip olup olmadığını belirlemek amacıyla analizler yapılmıştır. Bu karşılaştırmalarda cinsiyet, yaş, yaşama süresi, eğitim, meslek ve aylık gelir olmak üzere 6 bağımsız değişken kullanılmıştır. Bağımlı değişkenlerin iki seçenekli cinsiyet bağımsız değişkenine göre anlamlı bir farka sahip olup olmadığına bakılması için Mann-Whitney U testi; ikiden fazla seçenekli yaş, eğitim durumu, geçim tipi, aylık gelir gibi bağımsız değişkenlere göre ise, Kruskal-Wallis H testi kullanılmıştır. Aralarında istatistiksel olarak anlamlı farklılıklar bulunan karşılaştırmalar tablolar aracığı ile açıklanmış ve yorumlanmıştır.

Yerel halkın cinsiyetlerine göre turizmde yapabilecekleri işler arasında; ev pansiyonculuğu yapma, el işi ürünler üretip pazarlama ve yöresel yemek çeşitleri hazırlayıp pazarlama tutumlarında istatistiksel olarak anlamlı farklar görülmüsstür. Cinsiyete göre ev pansiyonculuğu yapma isteğinde erkeklerin (103.79) sıra ortalama değerleri bayanlara $(88,19)$ oranla daha yüksektir. Bayanların ev pansiyonculuğu yapma konusunda erkeklere oranla daha çekimser kaldıkları görülmüştür. MannWhitney U testi sonuçlarına göre; cinsiyete göre yerel halkın ev pansiyonculuğu yapmalarına ilişkin tutumları arasında erkeklerin lehine anlamlı farklılık bulunmuştur ( $p<0,05)$, (Çizelge 12).

El işi ürünler üretip pazarlama yapmaya ilişkin tutumlarının cinsiyete göre sahip olduğu anlamlı farklılıkta ise bayanların $(106,41)$ sıra ortalamaları erkeklere $(89,75)$ oranla daha yüksektir. MannWhitney U testi sonuçlarına göre; yerel halkın cinsiyetlerine göre el işi ürünler üretip pazarlamalarına ilişkin tutumları arasında bayanların lehine anlamlı farklılık bulunmuştur $(p<0,05)$, (Çizelge 12). Bu sonuca göre; kadınlar el işi ürünler üretip pazarlama konusunda erkeklere göre daha isteklidir.

Yöresel yiyecek ve içecekler sadece turizm destinasyonlarında tüketilmekle kalmaz; aynı zamanda hediyelik eşya olmaları bakımından da önemlidir. Turizm bölgelerinde özellikle bir yere özgü yiyecek ve içecekler; yemekle ilgili hediyelik eşya pazarının geliştirilebilmesi için dikkate değer bir potansiyeldir. Gıda ürünleri ucuz ve nispeten taşınması kolay oldukları için özellikle hediyelik eşya olarak önemlidirler (Richards, 2003). Yemek yeme zorunlu bir fiziksel ihtiyaç olduğu gibi yemeklerin pişirilmesi, kullanılan malzemeler bakımından da kültürü yansıtmaktadır. Özellikle bir yere özgü yiyecek ve içecekler otantik olmaları bakımından, turistik ürün olarak oldukça önemli etkileri vardır. Bu açıdan Osmaneli ilçe merkezinde yöresel yemek çeşitleri hazırlayarak bunları pazarlama, yerel halkın turizmde yapacağı en önemli işlerden biri olmaktadır. Cinsiyete göre yerel halkın, yöresel yemek çeşitleri hazırlayıp bunları pazarlamalarına ilişkin tutumları arasında kadınların lehine anlamlı farklılık bulunmuştur ( $\mathrm{p}<0,05)$, (Çizelge 12). Bu durum; kadınların yöresel yemek çeşitleri hazırlayıp pazarlama isteğinin daha fazla olduğunu göstermektedir. 
Çizelge 12. Cinsiyet ve turizme verilebilecek destek türlerinin karşılaştırılmasına ilişkin Mann-Whitney

\begin{tabular}{|c|c|c|c|c|c|c|c|c|}
\hline Destek türleri & Cinsiyet & $\mathrm{N}$ & $\begin{array}{c}\text { Sira } \\
\text { ortalamas1 }\end{array}$ & $\overline{\mathrm{X}}$ & SS & $\begin{array}{c}\text { Mann } \\
\text { Whitney } \\
\text { U }\end{array}$ & Z & $\mathrm{p}$ \\
\hline $\begin{array}{l}\text { Ev pansiyonculuğu } \\
\text { yapma }\end{array}$ & $\begin{array}{l}\text { Erkek } \\
\text { Kadın }\end{array}$ & $\begin{array}{c}109 \\
84\end{array}$ & $\begin{array}{c}103,79 \\
88,19\end{array}$ & 0,1865 & 0,39055 & 3838,000 & 2,851 & $0,004 *$ \\
\hline $\begin{array}{l}\text { El işi ürünler } \\
\text { üretip pazarlama }\end{array}$ & $\begin{array}{l}\text { Erkek } \\
\text { Kadın }\end{array}$ & $\begin{array}{c}109 \\
84\end{array}$ & $\begin{array}{c}89,75 \\
106,41\end{array}$ & 0,2953 & 0,45738 & 3787,500 & $\begin{array}{c}- \\
2,600\end{array}$ & $0,009 *$ \\
\hline $\begin{array}{l}\text { Yöresel yemek } \\
\text { çeşitleri hazırlayıp } \\
\text { pazarlama }\end{array}$ & $\begin{array}{l}\text { Erkek } \\
\text { Kadın }\end{array}$ & $\begin{array}{c}109 \\
84\end{array}$ & $\begin{array}{c}91,39 \\
104,27\end{array}$ & 0,1865 & 0,39055 & 3967,000 & 2,354 & $0,019 *$ \\
\hline
\end{tabular}

Yöresel yemek çeşitleri hazırlama ve Osmaneli'nde ikamet süresi arasındaki karşılaştırmada ise, genel ikamet süresi 16-20 yıl arasında olanların sıra ortalaması 124,41 ile ilk sırada yer almaktadır. Buna göre ikamet süresi arttıkça, yöresel yemek çeşitleri hazırlayıp bunları turizmde pazarlama tutumu artmaktadır. Kruskal Wallis H testi sonuçlarına göre, yerel halkın ikamet süresine göre; yöresel yemek çeşitleri hazırlayıp bunları pazarlamalarına ilişkin tutumları arasında anlamlı bir farklılık bulunmuştur ( $\mathrm{p}<0,05)$, (Çizelge 13).

Çizelge 13. İkamet süresi ve yöresel yemek çeşitleri hazırlayıp turizmde pazarlamaya ilişkin tutum, Kruskal Wallis $\mathrm{H}$ testi sonuçları

\begin{tabular}{|c|c|c|c|c|c|}
\hline \multirow{8}{*}{ 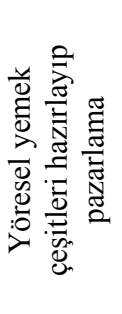 } & İkamet süresi & $\mathrm{N}$ & Sira ortalamas1 & $\chi^{2}$ & $\mathrm{p}$ \\
\hline & $1<$ & 13 & 93,85 & \multirow{7}{*}{13,674} & \multirow{7}{*}{$0,018^{*}$} \\
\hline & $1-5 \mathrm{y} 1 \mathrm{l}$ & 26 & 86,42 & & \\
\hline & 6-10 y1l & 16 & 109,16 & & \\
\hline & $11-15$ y1l & 21 & 97,38 & & \\
\hline & $16-20 \mathrm{y} 1 \mathrm{l}$ & 17 & 124,41 & & \\
\hline & $20>$ & 100 & 93,48 & & \\
\hline & Toplam & 193 & & & \\
\hline
\end{tabular}

Yerel halkın; yaş, eğitim durumu, geçimlerini sağlama biçimleri ve aylık gelir değişkenleri ile el işi ürünler üretip bunları turizmde pazarlama tutumu arasında Kruskal Wallis H testi sonuçlarına göre istatistiksel olarak anlamlı farklar bulunmuştur $(p<0,05)$, (Çizelge 14). El işi ürünler üretip pazarlama ile yaş grupları arasındaki karşılaştırmada 56-65 yaş arasındaki grubun 136,05 sıra ortalama değeri ile ilk sırada yer aldığ buna karşın 26-35 yaş arasındaki grubun 88,10 ile en son sırada yer aldığ tespit edilmiştir (Çizelge 14). Yaş gruplarına göre, yaş düzeyinin artması lehinde istatistiksel olarak anlamlı bir farklılık bulunmuştur $(\mathrm{p}<0,05)$, (Çizelge 14). Verilen cevaplara göre; yerel halkın yaş grubu arttıkça, el işi ürünler üretip bunları turizmde pazarlama tutumu artmaktadır. El işi ürünler üretip pazarlama ile eğitim seviyesi arasındaki karşılaştırmada ise okuma yazma bilen grup 132,83 ile en yüksek sıra ortalama değere sahiptir. İlkokul mezunları ise 123,18 ortalama değer ile onları takip etmiştir (Çizelge 14). Buna göre eğitim düzeyi azaldıkça, el işi ürünler üretip bunları turizmde pazarlama tutumu artmaktadır. Aylık gelire göre, el işi ürünler üretip bunları turizmde pazarlama tutumu arasında da istatistiksel olarak anlamlı bir farklılık bulunmuştur $(p<0,05)$, (Çizelge 14). Bu sonuca göre; aylık gelir düzeyi azaldıkça, el işi ürünler üretip bunları turizmde pazarlama tutumu artmaktadır. 
Çizelge 14. Yerel halkın özellikleri ile el işi ürünler üretilip pazarlamalarına ilişkin tutumlar, Kruskal Wallis H testi sonuçları

\begin{tabular}{|c|c|c|c|c|c|}
\hline \multirow{33}{*}{ 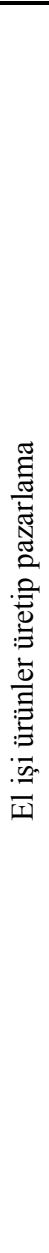 } & Yaş & $\mathrm{N}$ & Sira ortalamas1 & $\chi^{2}$ & $\mathrm{p}$ \\
\hline & $18-25$ & 37 & 91,97 & \multirow{7}{*}{12,481} & \multirow{7}{*}{$0,029 *$} \\
\hline & $26-35$ & 64 & 88,10 & & \\
\hline & $36-45$ & 46 & 97,87 & & \\
\hline & $46-55$ & 33 & 106,52 & & \\
\hline & $56-65$ & 10 & 136,05 & & \\
\hline & $65+$ & 3 & 100,67 & & \\
\hline & Toplam & 193 & & & \\
\hline & Eğitim düzeyi & $\mathrm{N}$ & Sira ortalamas1 & $\chi^{2}$ & $\mathrm{p}$ \\
\hline & Okuma yazma bilen & 6 & 132,83 & \multirow{9}{*}{23,293} & \multirow{9}{*}{$0,002 *$} \\
\hline & İlkokul & 30 & 123,18 & & \\
\hline & İlköğretim & 15 & 87,80 & & \\
\hline & Lise & 74 & 98,49 & & \\
\hline & Yüksek okul & 30 & 81,37 & & \\
\hline & Üniversite & 32 & 86,59 & & \\
\hline & Yüksek lisans & 5 & 68,50 & & \\
\hline & Doktora & 1 & 68,50 & & \\
\hline & Toplam & 193 & & & \\
\hline & Geçim tipi & $\mathrm{N}$ & Sira ortalamas1 & $\chi^{2}$ & $\mathrm{p}$ \\
\hline & Çiftçi & 11 & 112,36 & \multirow{8}{*}{30,729} & \multirow{8}{*}{$0,000^{*}$} \\
\hline & Hayvanc1 & 2 & 116,75 & & \\
\hline & Esnaf & 27 & 97,09 & & \\
\hline & İşçi & 49 & 96,07 & & \\
\hline & Memur & 62 & 76,28 & & \\
\hline & Emekli & 19 & 124,37 & & \\
\hline & Diğer & 23 & 123,04 & & \\
\hline & Toplam & 193 & & & \\
\hline & Aylık gelir & $\mathrm{N}$ & S1ra ortalamas1 & $\chi^{2}$ & $\mathrm{p}$ \\
\hline & $750 \mathrm{TL}<$ & 38 & 105,53 & \multirow{5}{*}{9,668} & \multirow{5}{*}{$0,022 *$} \\
\hline & $750-1500$ & 88 & 94,03 & & \\
\hline & $1500-2000$ & 37 & 81,84 & & \\
\hline & $2000>$ & 20 & 76,15 & & \\
\hline & Toplam & 183 & & & \\
\hline
\end{tabular}

Günümüzde, Osmaneli ilçesinde hâkim ekonomik faaliyet tarımdır. Nitekim ilçe genelinde toplam çalışan nüfusun \% 61.06'sı tarım; \% 18.49'u sanayi; \% 20.45'i hizmet sektöründe çalışmaktadır (Dincer ve Özaslan, 2004). Osmaneli ilçesinde kırsal bir ekonominin hâkim olduğu gözlenmektedir. Turizm yerel ekonomilerin canlanmasında önemli bir araçtır. Osmaneli'nde turizmin canlanması, tarımsal üretimin de arttırılmasında etkili olabilir. Yerel halkın geçimlerini sağlama biçimlerine göre; tarımsal ürünlerini turizmde pazarlamalarına ilişkin tutumları arasında anlamlı farklılık bulunmuştur $(p<0,05)$, (Çizelge 15). Hayvancı $(174,50)$, çiftçi $(148,18)$ ve esnaflıkla $(103,02)$ geçimini sağlayanlar ile tarımsal ürünlerini turizm amaçlı pazarlama arasında ortalama değerler en yüksektir (Çizelge 15). 
Çizelge 15. Yerel halkın geçimlerini sağlama biçimleri ile tarımsal ürünlerin pazarlanmasına ilişkin tutumlar; Kruskal Wallis H testi sonuçları

\begin{tabular}{|c|c|c|c|c|c|}
\hline \multirow{9}{*}{ 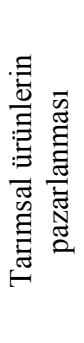 } & Geçim tipi & $\mathrm{N}$ & Sira ortalamas1 & $\chi^{2}$ & $\mathrm{p}$ \\
\hline & Çiftçi & 11 & 148,18 & \multirow{8}{*}{32,802} & \multirow{8}{*}{$0,000^{*}$} \\
\hline & Hayvanc1 & 2 & 174,50 & & \\
\hline & Esnaf & 27 & 103,02 & & \\
\hline & İşçi & 49 & 89,82 & & \\
\hline & Memur & 62 & 88,90 & & \\
\hline & Emekli & 19 & 98,32 & & \\
\hline & Diğer & 23 & 94,78 & & \\
\hline & Toplam & 193 & & & \\
\hline
\end{tabular}

\section{Sonuç ve Tartışma}

Osmaneli ilçe merkezinde yer alan geleneksel evler, anıtsal yapılar, devam eden birtakım gelenek ve görenekler bir dönemin ekonomik faaliyetlerinin mimariye ve yaşam tarzına nasıl etki ettiğini göstermektedir. Günümüzde hala 200 kadar geleneksel ev, çeşitli anıtsal yapılar ve yaşam tarzı ile devam eden bu miras, yeterince korunamamaktadır. Kültürel mirasın korunmasında, koruyarak kullanma yaklaşımı yani kültürel mirasın turizmde kullanılarak bir yandan korunması bir yandan da yöre ekonomisine katkıda bulunulması yaklaşımı günümüzde oldukça yaygındır. Bir yerde turizmin gelişmesinde yerel yönetimler ve yerel halk etkili olabilmektedir. Özellikle yerel halkın turizmin gelişmesi konusundaki tutumları bu konudaki en önemli belirleyicilerdendir. Çünkü turizmin etkilerini olumsuz algılayan yerel halk bölgedeki turizm gelişimini birçok açıdan sekteye uğratabilir. Bu nedenle turizmin gelişiminin sağlıklı bir yapıya kavuşabilmesi için yörede yaşayan yerel halkın turizme ilişkin algılarının ve tutumlarının bilinmesinde yarar vardır (Akova, 2006).

Yapılan değerlendirmelere göre; Osmaneli ilçe merkezinde yerel halk kültürel mirasın yeterince korunamadığ1 görüşündedir. Bununla birlikte yerel halk, kültürel mirasın korunması ve turizm faaliyetlerine karşı olumlu tutuma sahiptir. Literatürdeki bazı çalışmalarda; yerel halk, turizmi ekonomik gelişim sağlayan bir araç olarak görmektedir. Ayrıca, turizmin en önemli etkisinin ekonomik etkisi olduğunu düşünmektedir (Varnacı Uzun ve Somuncu, 2011). Bu bağlamda; geçimini büyük oranda tarımdan sağlayan yerel halkın büyük bir kısmı, turizm faaliyetlerine katılmak ve turizmden ekonomik fayda sağlamak istemektedir. Turizm faaliyetleri kapsamında yerel halk ilk üç sırada; el işi ürünler üretip pazarlayarak (\%29.5), turizm tesislerinde çalışarak (\%25.9) ve tarımsal ürünlerini pazarlayarak (\%19.7) turizme destek olabileceklerini belirtmişlerdir. Ancak yerel halk turizm konusunda yeterli bilgi ve deneyime sahip değildir.

Araştırmada yerel halkın demografik özellikleri ile turizmde ne gibi işler yapabilirsiniz sorularına verilen cevaplar arasında anlamlı bir fark olup olmadığı, Mann Whitney U ve Kruskal Wallis $\mathrm{H}$ testleri ile analiz edilmiştir. Mann Whitney U testi sonuçlarına göre; cinsiyet bağımsız değişkeninde; ev pansiyonculuğu yapma, el işi ürünler üretip pazarlama ve yöresel yemek çeşitleri hazırlayıp pazarlama tutumlarında istatistiksel olarak anlamlı farklar bulunmuştur. Buna göre; kadınlar ev pansiyonculuğu konusunda erkeklere göre daha çekimserdir. Ancak el işi ürünler üretip pazarlama ve yöresel yemek çeşitleri hazırlayıp pazarlama konusunda kadınlar erkeklere göre daha isteklidir. Bayanların turizm sayesinde el işi ürünler üretip bunları pazarlayarak gelir elde etmeleri, toplumsal statülerinin yükselmesi Beypazarı ve Safranbolu örneklerinde tecrübe edilmiştir. Ayrıca; turizmin Beypazarı'nda yarattığı pozitif etki alanı olarak \%75.38 el sanatlarının canlanması, \%73.85 yöresel yemeklerin korunup devam etmesi olarak belirlemişlerdir (Uslu ve Kiper, 2006).

Karşılaştırma yapılan bağımsız değişkenlerden; ikamet süresine göre yöresel yemek çeşitleri hazırlayıp pazarlama tutumu arasında istatistiksel olarak anlamlı bir farklılık bulunmuştur. Yerel halkın ikamet süresi arttıkça, yöresel yemek çeşitleri hazırlayıp pazarlama tutumları artmaktadır. Karşılaştırma yapılan bağımsız değişkenlerden; yaş, eğitim durumu, geçimlerini sağlama biçimleri ve aylık gelire göre el işi ürünler üretip pazarlama arasındaki tutum farklılıkları istatistiksel olarak 


\section{Kültürel Mirasın Korunması ve Turiżm Amaçlı Kullanılmasında Yerel Halkın Algı ve Tutumlarının Belirlenmesi}

anlamlı bulunmuştur. Buna göre; yaş grubu arttıkça, eğitim düzeyi ve aylık gelir düzeyi azaldıkça el işi ürünler üretip bunları turizmde pazarlama tutumu artmaktadır

$\mathrm{Bu}$ sonuçlardan hareketle, turizm faaliyetlerinin henüz yoğunluk kazanmadığı Osmaneli ilçe merkezinde, yerel halkın turizme katılımını sağlayacak planlamalar yapılması önerilmektedir. Böylece yöredeki kültürel mirasın korunmasına katkıda bulunulabilir. Sonuç olarak, bir turistik bölgede yerel halk tarafından turizmin algılanan olumsuz etkileri turizm gelişimine zarar verebilmektedir. Çevreye duyarlı, sürdürülebilir bir turizm gelişiminin gerçekleştirilebilmesi için yerel halkın algılamalarının ve tutumlarının düzenli aralıklarla ölçülmesi ve değerlendirilmesi gerekmektedir (Akova, 2006).

\section{Kaynaklar}

Aas, C.; Ladkin, A. and Fletcher, J. 2005. Stakeholder Collaboration and Heritage Management. Annals of Tourism Research, 32 (1): 28-48.

Akova, O. 2006. Yerel Halkın Turizmin Etkilerini Algılamalarına ve Tutumlarına Yönelik Bir Araştırma. Akademik Incelemeler Dergisi 2 (1): 1-34.

Andereck, K.L., Valentine, K.M., Knopf, R.C. and Vogt, C.A. 2005. Residents' Perceptions of Community Tourism Impacts. Annals of Tourism Research, 32 (4):1056-1076.

Anonim 2006. Bilecik Kültür Envanteri 2006. Bilecik Valiliği Yayını, İstanbul.

Bayram, M. 2011. Otel İşletmelerinin Genel Müdür Profillerinin Değerlendirilmesi Üzerine Bir Araştırma. Anatolia: Turizm Araştırmaları Dergisi, 22 (1): 35-48.

Besculides, A., Lee, M.E. and McCormick, P.J. 2002. Residents' Perceptions of the Cultural Benefits of Tourism. Annals of Tourism Research, 29(2): 303-319.

Binoy, T.A. 2011. Archaeological and Heritage Tourism Interpretation a Study. South Asian Journal of Tourism and Heritage. 4 (1):100-105.

Byrd, E.T., Bosley, H.E. and Dronberger, M.G. 2009. Comparisons of Stakeholder Perceptions of Tourism Impacts in Rural Eastern North Carolina. Tourism Management, 30 (5): 693-703.

Dincer, B. ve Özaslan, M. 2004. İlçelerin Sosyo- Ekonomik Gelişmişlik Stralaması Araştırması. Devlet Planlama Teşkilatı Yayınları, Ankara.

Garrod, F. and Fyall, A. 2000. Managing Heritage Tourism. Annals of Tourism Research. 27(3): 682-708.

Okuyucu, A. 2011. Osmaneli İlçe Merkezinde Kültürel Mirasın Korunması ve Turizm Amaçlı Kullanımına Yönelik Bir Araştırma. Yayınlanmamış Yüksek Lisans Tezi, Ankara Üniversitesi Sosyal Bilimler Enstitüsü, Coğrafya Anabilim Dall, Ankara.

Özdemir, M.A. ve Kervankıran, İ. 2011. Turizm ve Turizmin Etkileri Konusunda Yerel Halkın Yaklaşımlarının Belirlenmesi: Afyonkarahisar Örneği. Marmara Coğrafya Dergisi, 24: 1-25.

Özgür, E.M. 1990. Bilecik Coğrafyası. Yayınlanmamış Doktora Tezi, Ankara Üniversitesi Sosyal Bilimler Enstitüsü, Cografya Anabilim Dall, Ankara.

Poria, Y.; Butler, R. and Airey, D. 2003. The Core of Heritage Tourism. Annals of Tourism Research. 30 (1):238-254.

Richards, G. 2003. Gastronomy: An Essential Ingredient in Tourism Production and Consumption?. s. 3-21. Editor: G. Richards. Toursim and Gastronomy. Routledge, London.

Uluengin, B. ve Saatçi, S. 2009. Osmaneli ve Geleneksel Evleri. Kerkük Vakfi Yayınları, İstanbul.

Uriely, N.; Israeli, A.A. and Reichel, A. 2001. Heritage Proximity and Resident Attitudes Towards Tourism Development. Annals of Tourism Research. 29 (3):859-862.

Uslu, A. ve Kiper, T. 2006. Turizmin Kültürel Miras Üzerine Etkileri: Beypazarl/Ankara Örneğinde Yerel Halkın Farkındalığ. Tekirdağ Ziraat Fakültesi Dergisi, 3 (3): 305-313.

Varnacı Uzun, F. ve Somuncu, M. 2011. Kültürel Peyzajın Korunması ve Turizm İlişkisi Bağlamında Yerel Halkın Görüşleri: Ihlara Vadisi Örneği. Ankara Üniversitesi Çevre Bilimleri Dergisi. 3 (2): 21-36.

Williams, J. and Lawson, R. 2001. Community Issues and Resident Opinions of Tourism. Annals of Tourism Research, 28 (2): 269-290

Yeşiltaş, M. ve Demirçivi B.M. 2010. İş Görenlerin Yıldırma Eylemlerine Maruz Kalma Durumları Üzerine Bir Araştırma: Antalya Örneği. Anatolia: Turizm Araştırmaları Dergisi, 21 (2) 
Ayşe Okuyucu ve Mehmet Somuncu 